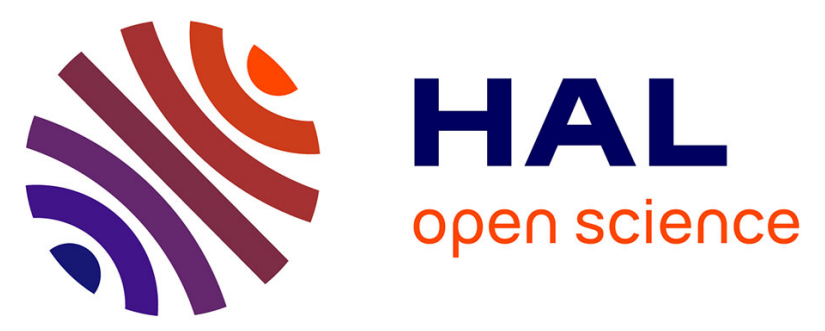

\title{
Copper and iron based thin film nanocomposites prepared by radio-frequency sputtering. Part II: elaboration and characterization of oxide/oxide thin film nanocomposites using controlled ex-situ oxidation process
}

Audrey Chapelle, Antoine Barnabé, Lionel Presmanes, Philippe Tailhades

\section{To cite this version:}

Audrey Chapelle, Antoine Barnabé, Lionel Presmanes, Philippe Tailhades. Copper and iron based thin film nanocomposites prepared by radio-frequency sputtering. Part II: elaboration and characterization of oxide/oxide thin film nanocomposites using controlled ex-situ oxidation process. Journal of Materials Science, 2013, 48, pp. 3304-3314. 10.1007/s10853-012-7116-5 . hal-00864120

\author{
HAL Id: hal-00864120 \\ https://hal.science/hal-00864120
}

Submitted on 20 Sep 2014

HAL is a multi-disciplinary open access archive for the deposit and dissemination of scientific research documents, whether they are published or not. The documents may come from teaching and research institutions in France or abroad, or from public or private research centers.
L'archive ouverte pluridisciplinaire HAL, est destinée au dépôt et à la diffusion de documents scientifiques de niveau recherche, publiés ou non, émanant des établissements d'enseignement et de recherche français ou étrangers, des laboratoires publics ou privés. 


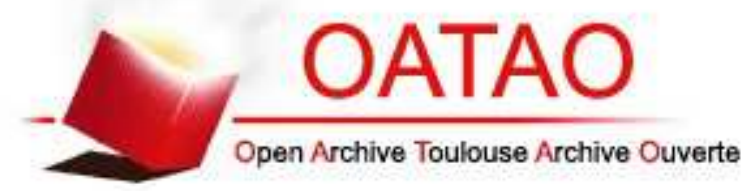

\section{Open Archive TOULOUSE Archive Ouverte (OATAO)}

OATAO is an open access repository that collects the work of Toulouse researchers and makes it freely available over the web where possible.

This is an author-deposited version published in : http://oatao.univ-toulouse.fr/ Eprints ID : 9428

To link to this article : doi:10.1007/s10853-012-7116-5

URL : http://dx.doi.org/10.1007/s10853-012-7116-5

To cite this version : Chapelle, Audrey and Barnabé, Antoine and Presmanes, Lionel and Tailhades, Philippe Copper and iron based thin film nanocomposites prepared by radio-frequency sputtering. Part II: elaboration and characterization of oxide/oxide thin film nanocomposites using controlled ex-situ oxidation process. (2013) Journal of Materials Science, 48 (8). pp. 3304-3314. ISSN 0022-2461

Any correspondance concerning this service should be sent to the repository administrator: staff-oatao@ listes-diff.inp-toulouse.fr 


\title{
Copper and iron based thin film nanocomposites prepared by radio-frequency sputtering. Part II: elaboration and characterization of oxide/oxide thin film nanocomposites using controlled $e x$-situ oxidation process
}

\author{
A. Chapelle • A. Barnabé · L. Presmanes • \\ P. Tailhades
}

\begin{abstract}
CuO} / \mathrm{CuFe}_{2} \mathrm{O}_{4}$ thin films were obtained on glass substrate by ex situ oxidation in air at $450{ }^{\circ} \mathrm{C}$ for $12 \mathrm{~h}$ from various starting metal/oxide nanocomposites by radio-frequency sputtering technique. The structure and microstructure of the films were examined using grazing incidence X-ray diffraction, Raman spectroscopy, scanning and transmission electron microscopies, X-ray photoelectron spectroscopy, and electron probe microanalysis. These studies reveal that a selforganized bi-layered microstructure with $\mathrm{CuO}$ (surface layer) and $\mathrm{CuFe}_{2} \mathrm{O}_{4}$ (heart layer) was systematically obtained. Due to the porosity of the upper layer formed during annealing, an increase in total thickness of the film was observed and is directly correlated to the oxidation of the metallic copper content initially present in the as-deposited sample. A selforganization in two stacked layers $\mathrm{CuO} / \mathrm{CuFe}_{2} \mathrm{O}_{4}$ with various void fractions ranging from 0 to $41 \%$ can be obtained by controlling the as-deposited elaboration step described in the part I of this paper. The highest porosities were observed for films deposited at low argon pressure and low target-to-substrate distance. Due to their specific self-organization in p-and n-type layers associated with their high porosity, such structured films exhibited the best electrical sensitivity to $\mathrm{CO}_{2}$ gas sensing. The obtained results demonstrated the importance of microstructure control to improve the response of sensing layers.
\end{abstract}

Keywords Copper oxide $\cdot$ Spinel ferrite $\cdot$ Gas sensor

\footnotetext{
A. Chapelle · A. Barnabé $(\bowtie) \cdot$ L. Presmanes · P. Tailhades Institut Carnot CIRIMAT, UMR CNRS 5085, Université Paul Sabatier Toulouse III, 118, Route de Narbonne,

31062 Toulouse Cedex 4, France

e-mail: barnabe@chimie.ups-tlse.fr
}

\section{Introduction}

Advanced engineering applications often require multifunctional materials with a wide range of tunable properties. Due to the difficulty to fulfill such a technological demand using single-phase materials, there is an increasing need to combine materials with complementary properties to achieve certain technological goals. Nanocomposites are a fascinating class of materials, owing not only due to their fundamental interests but also due to their practical advanced applications $[1,2]$.

Although the major exploitation of such materials in the form of thin films was in the fields of tribology and microelectronics, today thin film research in the areas of energy generation, catalysis, and sensor technology has tremendously been increased. Some of the physical and chemical properties related to interfacial effects are improved in nanocomposite structures with respect to coarse-grained multi-component materials. Furthermore, some interesting size effects can also emerge in materials when its structure is made nanocrystalline. This has prompted the development of novel types of composite materials and the concomitant implementation of innovative processing routes [3].

The recent surge of interest in thin film composites made of $\mathrm{n}$ - and p-type semiconductor metal oxides has been especially aroused because of some specific properties. This type of composite exhibits indeed, unusual photocatalytic properties [4] or unusual high sensitivity and high selectivity to reducing or oxidizing gas species, as compared with their bulk or individual counterparts [5].

Due to their interesting properties for $\mathrm{CO}$, ethanol, or acetone sensors [6, 7], p-type semiconductors copper oxides were advantageously combined with other n-type oxides to detect weakly reactive molecules. For the $\mathrm{CO}_{2}$ detection for instance, some authors have already reported efficient 
composite materials based on the association of various metal oxides with $\mathrm{CuO}$ [8-12].

In this paper, composites thin films made of $\mathrm{CuO}$ and $\mathrm{CuFe}_{2} \mathrm{O}_{4}$ will be studied. These composites are obtained by a proper oxidation of the copper/oxides thin film samples previously studied in the part I of this work [13]. They are original and very interesting because they are made of p-type and n-type semiconducting oxides on the one hand, and because they display an original stratified organization, on the other hand. The stratification comes from a self-structuration induced by the oxidation of metallic copper and cuprous oxide making the starting $\mathrm{Cu} /\left(\mathrm{Cu}_{2} \mathrm{O}, \mathrm{Cu}_{x} \mathrm{Fe}_{3-x} \mathrm{O}_{4}\right)$ nanocomposites. These oxidations leave porosity mainly in the upper $\mathrm{CuO}$ layer, which could play a major role in the sensing properties of the $\mathrm{CuO} / \mathrm{CuFe}_{2} \mathrm{O}_{4}$ films. Due to the great influence of the microstructure on gas sensing properties [14], the study of the $\mathrm{CuO} / \mathrm{CuFe}_{2} \mathrm{O}_{4}$ composites at the micrometric and nanometric scale, will then be the main concern of this paper. Some gas sensing experiments will be, however, carried out to demonstrate that these new materials are really interesting for gas sensor applications due to both their composition and their specific structuration at the micronic and nanometric scales.

\section{Experimental methods}

\section{Thin films elaboration}

In the first step, thin films were prepared by non-reactive radio-frequency sputtering from a homemade $\mathrm{CuFeO}_{2}$ ceramic target using an Alcatel A450 apparatus. A previous study (part I of this paper [13]) reveals that the films consist of copper nanoparticles, which are embedded in an oxide matrix. These nanocomposites metal/oxides thin films were obtained with different metallic and oxide phases content according to the deposition conditions (argon pressure $P$ ranging from 0.5 to $2.0 \mathrm{~Pa}$ and target-to-substrate distance $d$ ranging from 5 to $8 \mathrm{~cm})$. Four samples deposited with extreme pressures $(0.5$ and $2.0 \mathrm{~Pa})$ and target-to-substrate distances $(5$ and $8 \mathrm{~cm})$ are presented in this work and noted $P_{0.5} d_{5}, P_{0.5} d_{8}, P_{2.0} d_{5}$, and $P_{2.0} d_{8}$. All the as-deposited samples were prepared with a constant thickness of $300 \mathrm{~nm}$. In the second step, these as-deposited samples were annealed in air at $450{ }^{\circ} \mathrm{C}$ for $12 \mathrm{~h}$ to obtain the required copper and iron based oxide thin film nanocomposites. All the process parameters of both steps are summarized in Table 1. The as-deposited and annealed samples presented in this work are noted $P_{0.5} d_{5}, P_{0.5} d_{8}, P_{2.0} d_{5}$, and $P_{2.0} d_{8}$ in reference to the deposition conditions.

Thin film characterizations

The structure and microstructure of the as-deposited samples were already reported in a previous work [13]. This
Table $1 \mathrm{CuO} / \mathrm{CuFe}_{2} \mathrm{O}_{4}$ nanocomposites process parameters (deposition by rf-sputtering and post-annealing treatment)

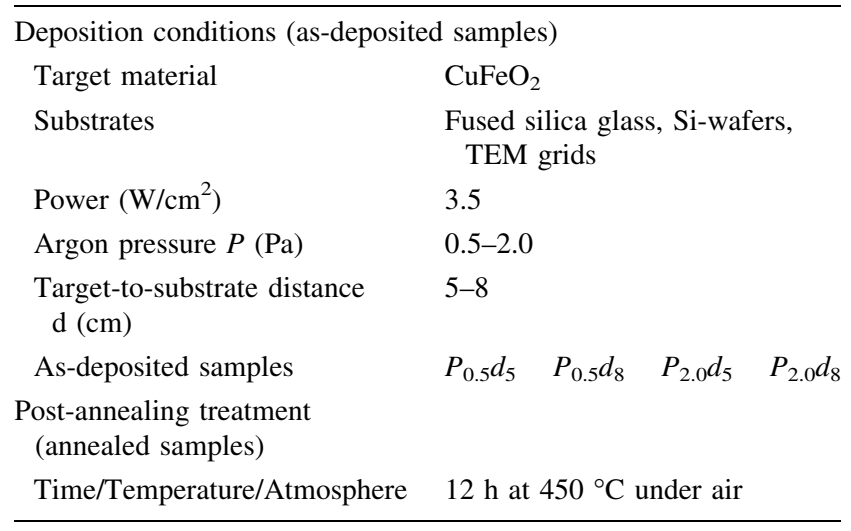

part deals with the characterization of the above samples after annealing in air at $450{ }^{\circ} \mathrm{C}$ for $12 \mathrm{~h}$. In situ temperature X-ray diffraction (TXRD) experiments were carried out using a Bruker D8 Advance diffractometer equipped with a Bruker LynxEye 1D detector and with a HTK1200N Anton Paar high temperature attachment in $\theta-\theta$ geometry. The diffraction patterns were scanned over a $29-46^{\circ}$ range in $2 \theta$ with a step of $0.022^{\circ}$, a counting time of $1.5 \mathrm{~s} / \mathrm{step}$ and with a temperature step of $25{ }^{\circ} \mathrm{C}$ from room temperature to $500{ }^{\circ} \mathrm{C}$. Ex situ grazing incidence XRD (GIXRD) patterns at room temperature were collected on a Siemens D5000 apparatus (grazing angle $\alpha=1^{\circ}$ ) equipped with a Bruker SolX detector. Diffraction patterns were scanned over a $20-80^{\circ}$ range in $2 \theta$ with a step of $0.03^{\circ}$ and a counting time of $7 \mathrm{~s} / \mathrm{step}$.

The Raman spectra were collected under ambient conditions using a Horiba Scientific Raman microscope fitted with a laser wavelength of $532 \mathrm{~nm}$ and a $100 \times$ objective lens. During the measurement, the resulting laser power at the surface of the sample was adjusted at $1.1 \mathrm{~mW}$. The final spectrum is the average of three accumulations of $300 \mathrm{~s}$. Examination of multiple spots showed that the samples were homogeneous.

Microstructural studies were carried out with a JEOL JSM 6400 field emission gun scanning electron microscope (FE-SEM). The specimens were cut with a diamond tip and immediately fixed close to the normal of the sample holder for cross-sectional FE-SEM analyses.

Chemical compositions of the films, determined by electron probe micro-analysis (EPMA), were carried out with a Cameca SX 50 apparatus. The analyses were performed on films deposited on silicon substrate. The $\mathrm{Si}$ substrate provided an oxygen free support after the removal of the thin $\mathrm{SiO}_{2}$ layer with hydrofluoric acid, from which the complete sample composition could be determined. The final average value corresponds to a minimum of ten measurements. A Thermo Scientific K-Alpha apparatus 
was used for X-ray photoelectron spectroscopy (XPS) measurements, using a monochromatic $\mathrm{Cu} \mathrm{K \alpha}$ radiation with a $400 \mu \mathrm{m}$ spot size. Peaks were scanned at $50 \mathrm{eV}$ pass energy. The spectrometer was equipped with ions gun to realize depth profile by etching technique. Flood gun was used to minimize charging effects. The binding energies (BE) were referenced to the $1 \mathrm{~s}$ carbon peak (atmospheric contamination) at $284.6 \mathrm{eV}$.

Gas sensing properties measurements

The $\mathrm{CO}_{2}$ sensing characteristics were measured by a twoprobe method. The $\mathrm{CuO}-\mathrm{CuFe}_{2} \mathrm{O}_{4}$ based sensors were mounted on a quartz tube inside a tubular furnace which is connected to a gas flow system. The gases were continuously flown through the cell at a total flow rate of $100 \mathrm{sccm}$. Cylinder supplies equipped with mass flow regulators were used to set the $\mathrm{CO}_{2}$ concentrations at 5,000 ppm. Dry synthetic air was used as a reference gas in this study. The sensor output resistance was recorded as a function of time using a Keithley 2001 multimeter. The sensor response $S$ was defined as $S(\%)=100 \times \frac{R_{\mathrm{CO}_{2}}-R_{\mathrm{Air}}}{R_{\mathrm{Air}}}$, where $R_{\mathrm{Air}}$ is the resistance of the sensor in dry air, and $R_{\mathrm{CO}_{2}}$ is the resistance of the sensor under carbon dioxide flow. The thickness of the films used for the measurement of electrical resistance and gas sensing behavior was set to $50 \mathrm{~nm}$. The films were first heated to $500{ }^{\circ} \mathrm{C}$ under air flow in the measuring cell to remove all the contaminating species adsorbed at the surface of the sensing layer, then stabilized at $250{ }^{\circ} \mathrm{C}$ for recording the resistance.

\section{Results and discussion}

Structural analysis

As previously reported in part I of this paper [9], the overall deposition process, which starts from a $\mathrm{CuFeO}_{2}$ target and ends to the formation of films made of different proportions of copper, copper oxide, and iron oxide, could be schematically described by the global following equation:

$$
\begin{gathered}
\mathrm{CuFeO}_{2} \stackrel{\text { sputteringprocess }}{\rightarrow} A \mathrm{Cu}+\frac{1-A}{2} \mathrm{Cu}_{2} \mathrm{O} \\
+\frac{9-A}{24}\left(\mathrm{Fe}_{\frac{24-8 A}{9-A}}^{3+} \mathrm{Fe}_{\frac{8 A}{9-A}}^{2+} \square_{\frac{3-3 A}{9-A}} \mathrm{O}_{4}^{2-}\right)+\frac{A}{3} \mathrm{O}_{2}
\end{gathered}
$$

where the $A$ ratio represents the reaction progress between the strict duplication of the target material $\mathrm{CuFeO}_{2}$ and the complete reduction of the copper species. For the films deposited with the $P_{0.5} d_{5}, P_{0.5} d_{8}, P_{2.0} d_{5}$, and $P_{2.0} d_{8}$ conditions, the A ratio which is also the copper metallic content for one mole of the $\mathrm{CuFeO}_{2}$ target material was found to be equal to $0.31,0.22,0.12$, and 0.03 , respectively. The rest of the oxide matrix is made of cuprous oxide and mixed valence defect ferrite.

All of these phases described by Eq. 1, i.e., copper, copper oxide, and iron oxide, will be affected by the heat treatment in air at $450{ }^{\circ} \mathrm{C}$.

According to the literature, cuprite $\left(\mathrm{Cu}_{2} \mathrm{O}\right)$ and tenorite $(\mathrm{CuO})$ are the main oxidation products of copper nanoparticles [15]. Two oxidation regimes are usually observed at low temperature. The first one appears when copper is oxidized at temperature below the $\mathrm{CuO}$ dissociation temperature (the line between the cupric and cuprous oxide in the pressure-temperature phase diagram); in this case a single layer of $\mathrm{Cu}_{2} \mathrm{O}$ is formed over the copper. For copper nanoparticles with a mean diameter of $20 \mathrm{~nm}$ in a $20 \%$ oxygen-nitrogen atmosphere, this temperature was determined to be at around $200{ }^{\circ} \mathrm{C}$ by mass gain measurements [16]. Lower temperature was also reported by electrical measurements for smaller sizes of copper particles in nanocomposite thin films [17]. The second regime is observed at higher temperature or oxygen pressure above the dissociation pressure. In this case, the oxidation is called double layer oxidation because, at first, a layer of $\mathrm{CuO}$ is formed over copper, but subsequently, a layer of $\mathrm{Cu}_{2} \mathrm{O}$ is formed between copper and cupric oxide. These two layers increase with time. Increasing temperature of oxidation intensifies the recrystallization of tenorite crystals to greater extent than that of cuprite and contributes into slowing copper oxidation to equilibrium single-phased $\mathrm{CuO}$ [18]. One can note that in this case, the oxidation takes place by copper ions diffusion toward the oxide/ oxygen interface.

For the mixed valence defect ferrite which may be considered as a combination of magnetite with $\gamma-\mathrm{Fe}_{2} \mathrm{O}_{3}$ stabilized in the spinel structure type due to the surface energy $[19,20]$, the heat treatment will just induce the oxidation of the ferrous into ferric ions. More generally in the $\mathrm{Cu}-\mathrm{Fe}-\mathrm{O}$ system, the reaction between copper and iron oxides leads to the formation of delafossite $\left(\mathrm{CuFeO}_{2}\right)$ and cupro-spinel $\left(\mathrm{CuFe}_{2} \mathrm{O}_{4}\right)$ phases in function of the stoichiometry, temperature, and oxygen partial pressure [21, 22]. $\mathrm{CuO} / \mathrm{CuFe}_{2} \mathrm{O}_{4}$ thin film systems under identical atmosphere and temperature were already reported [17].

From the complete overall deposition equation described in Eq. 1 and balanced with the ratio $A$, the heat treatment at $450{ }^{\circ} \mathrm{C}$ in air could form tenorite and cupro-spinel phases by oxidation. Such a heat treatment leads to cuprous and ferric cations, which are combined, due to their respective proportions, in a $\mathrm{CuFe}_{2} \mathrm{O}_{4}$ spinel phase on the one hand and in a $\mathrm{CuO}$ phase on the other hand. The annealing treatment of the as-deposited samples can then be represented by the following equation: 


$$
\begin{aligned}
& A \mathrm{Cu}+\frac{1-A}{2} \mathrm{Cu}_{2} \mathrm{O}+\frac{9-A}{24}\left(\mathrm{Fe}_{\frac{24-8 A}{9-A}}^{3+} \mathrm{Fe}_{\frac{8 A}{9-A}}^{2+} \square_{\frac{3-3 A}{9-A}} \mathrm{O}_{4}^{2-}\right) \\
& +\frac{4 A+3}{12} \mathrm{O}_{2} \\
& \quad \rightarrow \frac{1}{2} \mathrm{CuO}+\frac{1}{2} \mathrm{CuFe}_{2} \mathrm{O}_{4}
\end{aligned}
$$

Figure 1 shows the GIXRD patterns of the $P_{0.5} d_{5}$, $P_{0.5} d_{8}, P_{2.0} d_{5}$, and $P_{2.0} d_{8}$ thin films, annealed in air for $12 \mathrm{~h}$ at $450{ }^{\circ} \mathrm{C}$. All the characteristic peaks of the tenorite phase are present in accordance with Eq. 2. However, the $\mathrm{CuFe}_{2} \mathrm{O}_{4}$ cupro-spinel phase is surprisingly missing in the GIXRD patterns except a small intensity peak located around $30^{\circ}$ in $2 \theta$ which can be attributed to the $\mathrm{CuFe}_{2} \mathrm{O}_{4}$ (220) Bragg reflexion. An annealing in air at $450{ }^{\circ} \mathrm{C}$ for longer time (48 h) of the $P_{0.5} d_{5}$ sample confirms, however, the presence of the cupro-spinel phase. The characteristic peaks on the X-ray patterns remain tiny, as shown in the upper graph of Fig. 1.

In order to observe the phases formation described in Eq. 2, in situ TXRD experiments were carried out on the samples corresponding to the two extreme deposition conditions. The $P_{0.5} d_{5}$ and $P_{2.0} d_{8}$ samples were thus studied by TXRD from 25 to $500{ }^{\circ} \mathrm{C}$. The corresponding TXRD patterns are presented in Fig. 2.

For the $P_{0.5} d_{5}$ sample which contained the highest amount of metallic copper $(A=0.31)$ in the as-deposited form, Fig. 2 shows several steps of phase formation. From room temperature to $175{ }^{\circ} \mathrm{C}$, only one peak is observed at $2 \theta=43.5^{\circ}$. It corresponds to the (111) Bragg peak of metallic copper. No characteristic peak of the oxide matrix can be detected in this temperature range because of its nanocrystalline nature and the possible ongoing reaction between the metastable mixed valence defect ferrite and cuprite phases [13]. The metallic copper (111) Bragg peak area decreases from $175^{\circ} \mathrm{C}$ while a peak located at $2 \theta=36.4^{\circ}$ corresponding to cuprite (111) Bragg reflexion appears from this temperature. The temperature of $175^{\circ} \mathrm{C}$ is in good agreement with the oxidation temperature of the metallic copper into $\mathrm{Cu}_{2} \mathrm{O}$ referenced in the literature [16, 17, 23-25]. From 200 to $300{ }^{\circ} \mathrm{C}$ the $\mathrm{Cu}_{2} \mathrm{O}$ (111) Bragg peak is clearly observed and becomes more intense. Then, for higher temperatures, two peaks appear at $2 \theta=35.5^{\circ}$ and $2 \theta=38.5^{\circ}$ assigned to the (111), (002), and (111) Bragg reflections of the tenorite. The higher intensities of the (111) and (002) Bragg peaks may be due to the overlapping of the (311) main Bragg peak of the cupro-spinel phase, even if this phase is not clearly visible elsewhere. As a result, for this sample, the tenorite phase comes from the oxidation of the copper nanoparticles in association with the oxidation of $\mathrm{Cu}_{2} \mathrm{O}$ initially present in the as-deposited sample.

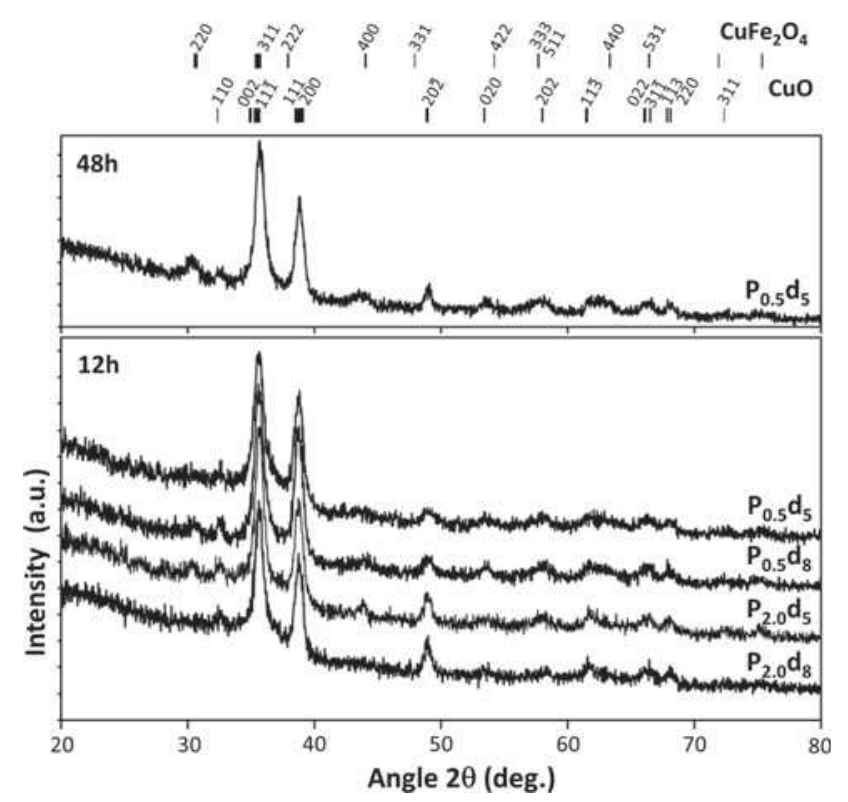

Fig. 1 GIXRD patterns of the $P_{0.5} d_{5}, P_{0.5} d_{8}, P_{2.0} d_{5}$, and $P_{2.0} d_{8}$ samples annealed $12 \mathrm{~h}$ at $450{ }^{\circ} \mathrm{C}$ under air and $48 \mathrm{~h}$ for $P_{0.5} d_{5}$

The same experiment was done on the $P_{2.0} d_{8}$ sample (Fig. 2). This sample initially contained less metallic copper $(A=0.03)$ and is mainly constituted of a nanocrystallized mixed valence defect ferrite and the cuprite phases. This is confirmed with the in situ TXRD patterns whereas cuprite phase due to copper oxidation is not visible at low temperature. However, above $325^{\circ} \mathrm{C}$, the peak at $2 \theta=35^{\circ}$ is shifted to higher values of $2 \theta$ and a second peak appears at $2 \theta=38.5^{\circ}$. These two peaks correspond to the $\mathrm{CuO}$ (111) and (111) Bragg peaks, respectively. In contrast to the previous sample, the $\mathrm{CuO}$ does not come from the oxidation of metallic copper but mainly from the oxidation of $\mathrm{Cu}_{2} \mathrm{O}$ present initially in the as-deposited sample.

The presence of tenorite and cupro-spinel phases in the annealed samples are confirmed by Raman experiments. Figure 3 presents the Raman spectra of the four annealed samples in air. The Raman spectra show bands at 289, 337, 621,1098 , and $1211 \mathrm{~cm}^{-1}$ characteristic of the $\mathrm{CuO}$ phase and at $468,531,705,808$, and $1321 \mathrm{~cm}^{-1}$ corresponding to $\mathrm{CuFe}_{2} \mathrm{O}_{4}$ phase according to the reference samples registered in the same conditions. The most visible peaks on the spectra are those attributed to the $\mathrm{CuO}$, in accordance with the GIXRD measurements. One can note that the bands located at 468 and $705 \mathrm{~cm}^{-1}$ and attributed to the cupro-spinel phase, tend to increase from $P_{0.5} d_{5}$ to $P_{2.0} d_{8}$, i.e., as the metallic copper content decreases in the as-deposited samples.

Morphological and compositional analysis

The microstructure of all the annealed samples was determined by cross-sectional FE-SEM analysis. As shown in 

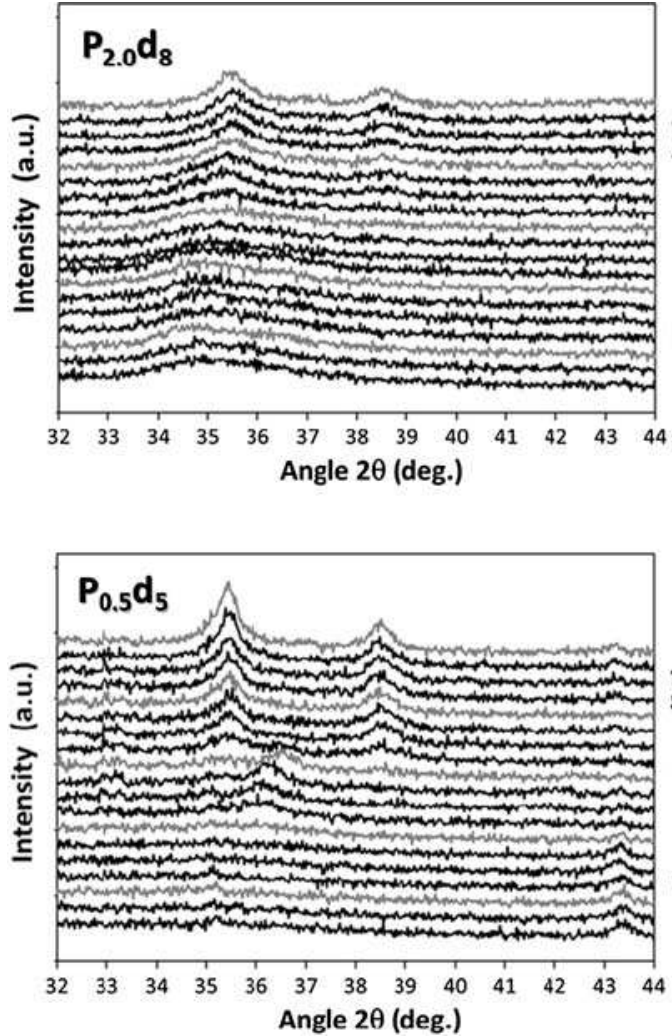

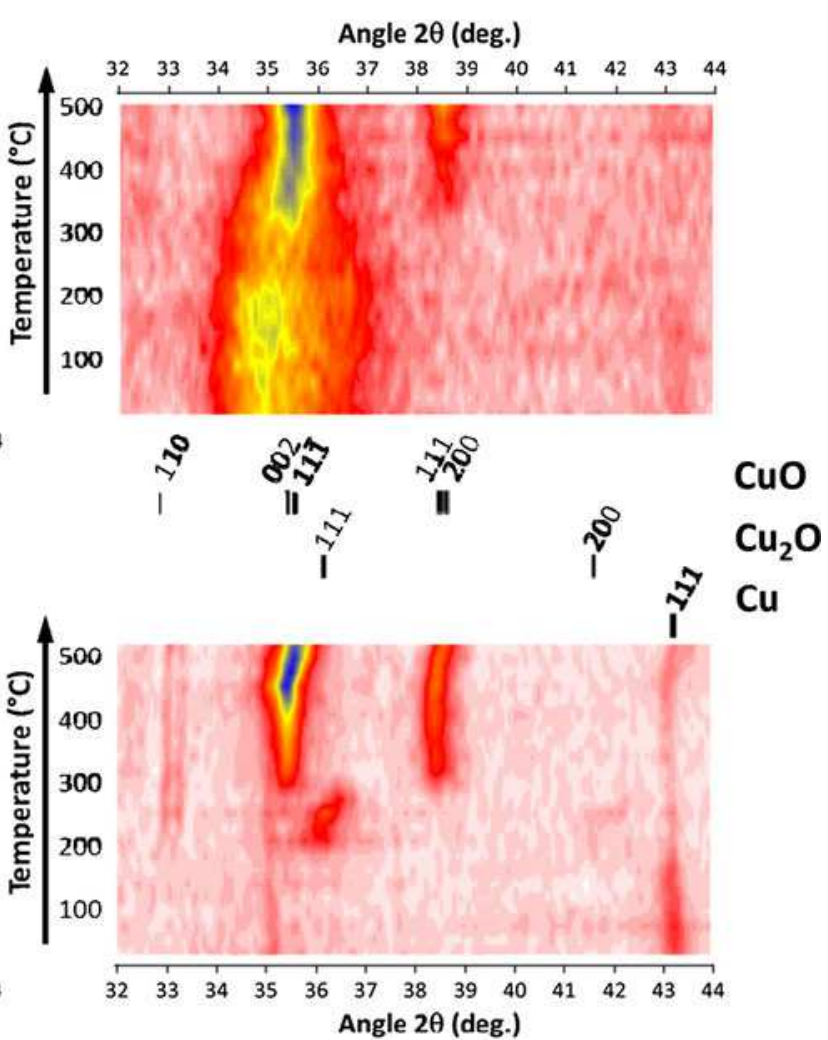

Fig. 2 In situ XRD patterns of the $P_{0.5} d_{5}$ and $P_{2.0} d_{8}$ samples from 25 to $500{ }^{\circ} \mathrm{C}$ with steps of $25{ }^{\circ} \mathrm{C}$. The intensities are also represented in color plot versus angle $2 \theta$ ( $x$-axis) and temperature (y-axis) (Color figure online)

Fig. 4a, for the $P_{0.5} d_{5}$ and $P_{2.0} d_{8}$ annealed samples, the thin films exhibit a two layers structure stacked on each other, which will be named from now on by heart layer (HL) and surface layer (SL). With thicknesses of 120 and $60 \mathrm{~nm}$, the SLs are thinner than the HLs $(270$ and $250 \mathrm{~nm})$ for $P_{0.5} d_{5}$ to $P_{2.0} d_{8}$ samples, respectively. Both $P_{0.5} d_{5}$ and $P_{2.0} d_{8}$ annealed samples are smooth and have uniform total thicknesses of 390 and $310 \mathrm{~nm}$, respectively. These thicknesses are significantly higher than the $300 \mathrm{~nm}$ of the as-deposited samples. The plane view FE-SEM micrographs of the pertaining samples are shown in Fig. $4 \mathrm{~b}$.

Considering this original rearrangement in two stacked layers, XPS destructive analysis by etching was carried out to know the composition variation versus the thin film depth. A representative XPS survey spectrum obtained after removing the first ten nanometers of the polluted surfaces is displayed in Fig. 5a. It corresponds to the airannealed 300-nm-thick $P_{0.5} d_{5}$ sample. It shows photoelectron lines for $\mathrm{Cu} 2 \mathrm{p}, \mathrm{O} 1 \mathrm{~s}, \mathrm{C} 1 \mathrm{~s}$, and the Auger lines LMM. Apart from a very weak carbon C1s peak, which we associate with adventitious hydrocarbon at the top surface, only copper and oxygen core levels are observed in both spectra. As shown in Fig. 5a insert, the XPS spectra present two peaks on the $\mathrm{Cu} 2 \mathrm{p}$ spectrum $(\mathrm{BE}=934.5$ and $954.5 \mathrm{eV}$ ). These two peaks are assigned to the $\mathrm{BE}$ of

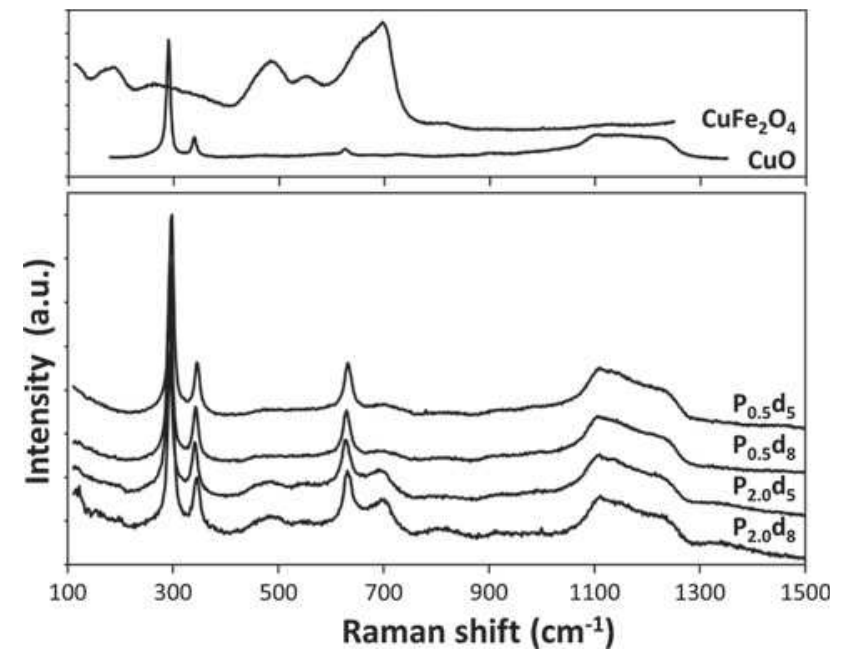

Fig. 3 Raman spectra of the $P_{0.5} d_{5}, P_{0.5} d_{8}, P_{2.0} d_{5}$, and $P_{2.0} d_{8}$ samples annealed $12 \mathrm{~h}$ at $450{ }^{\circ} \mathrm{C}$ under air. Raman spectra of $\mathrm{CuO}$ and $\mathrm{CuFe}_{2} \mathrm{O}_{4}$ commercial powders are also plotted for comparison

$\mathrm{Cu} 2 \mathrm{p}_{3 / 2}$ and $\mathrm{Cu} 2 \mathrm{p}_{1 / 2}$ in $\mathrm{CuO}$, respectively. Two other satellite peaks appear on the higher binding energy side for both $\mathrm{Cu} 2 \mathrm{p}_{3 / 2}$ and $\mathrm{Cu} 2 \mathrm{p}_{1 / 2}(\mathrm{BE}=943.6$ and $962.3 \mathrm{eV})$. These satellites can be attributed to shake-up transitions by ligand-to-metal $3 d$ charge transfer [26-28]. This charge 
Fig. 4 a FE-SEM micrographs in cross-sectional view of the $P_{0.5} d_{5}$ and $P_{2.0} d_{8}$ samples annealed $12 \mathrm{~h}$ at $450{ }^{\circ} \mathrm{C}$ under air. Schematic representations of the films are shown for the as-deposited and annealed samples. For the latter, heart and SLs are noted HL and SL, respectively. b FE-SEM micrographs in plane view of the $P_{0.5} d_{5}$ and $P_{2.0} d_{8}$ samples annealed $12 \mathrm{~h}$ at $450{ }^{\circ} \mathrm{C}$ under air
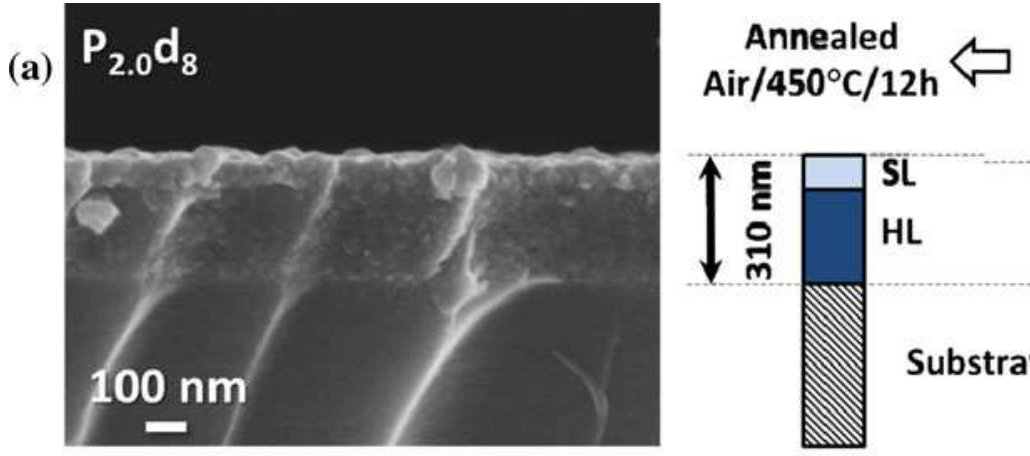
As-deposited $\mathbf{P}_{2.0} \mathrm{~d}_{8}$
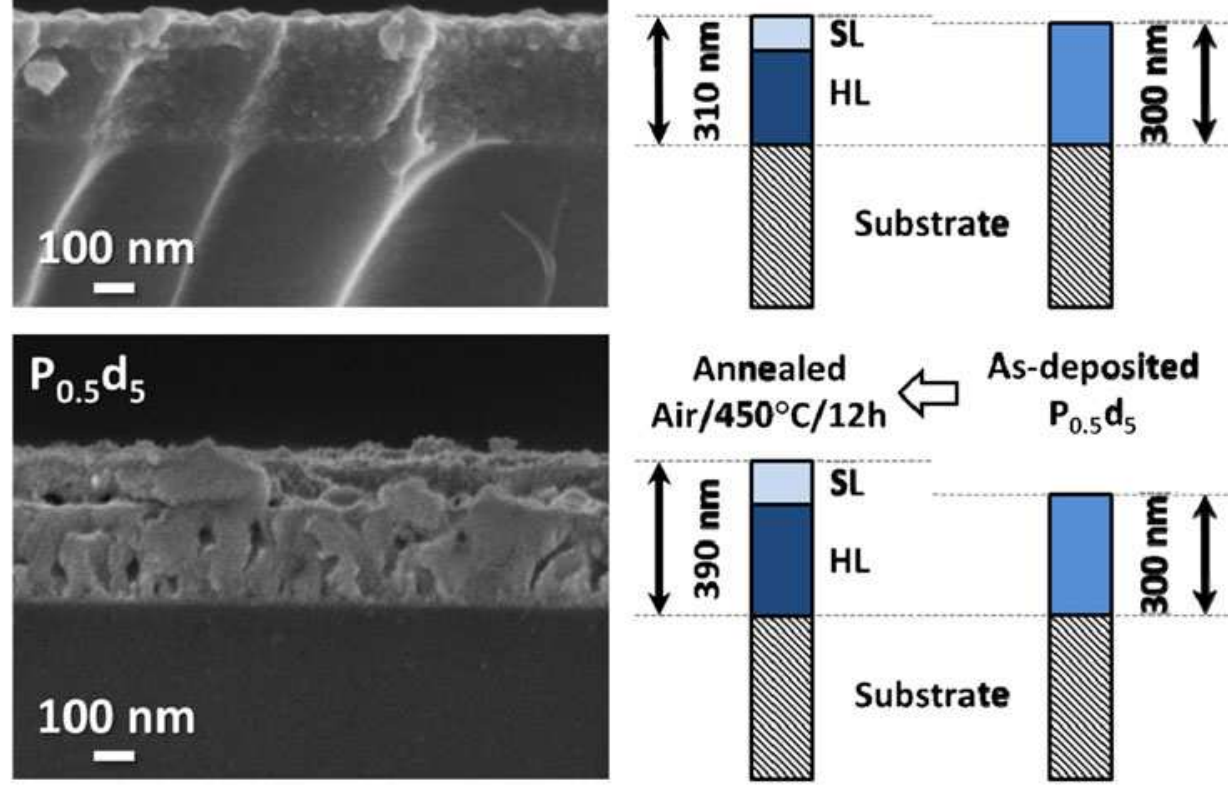

(b)

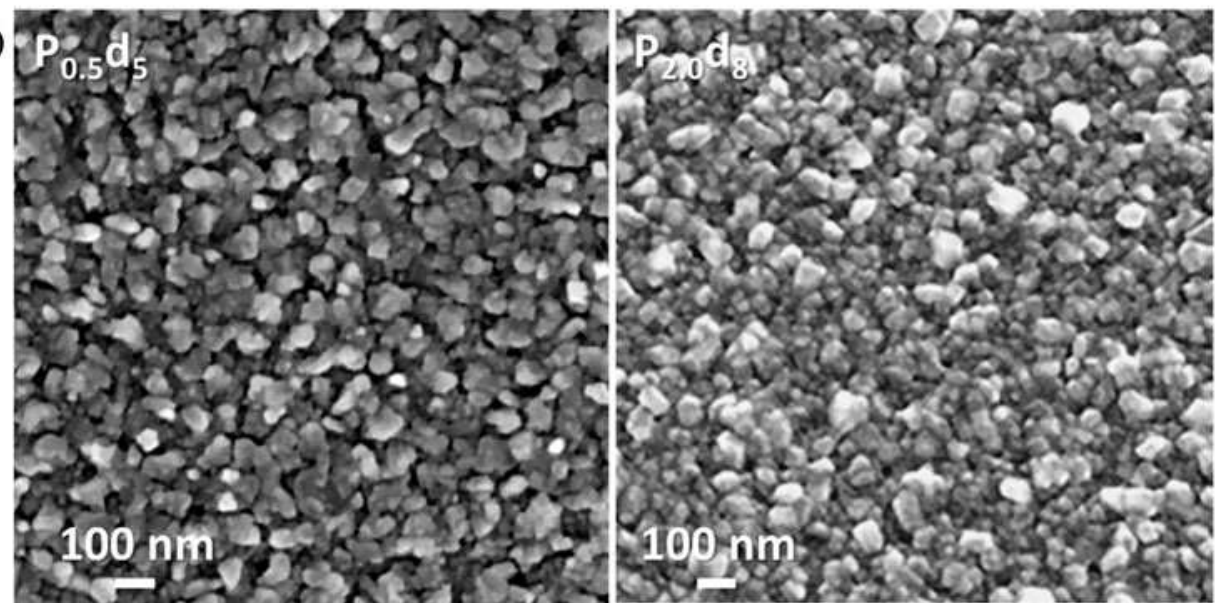

transfer can occur for copper in $\mathrm{Cu}$ (II) oxidation state $\left(3 d^{9}\right.$ configuration) but cannot take place for metallic or $\mathrm{Cu}(\mathrm{I})$ species $\left(3 d^{10}\right.$ configuration) because of their completely filled $3 d$ shells. The composition of the film was analyzed between two consecutive $\mathrm{Ar}^{+}$ion bombardments. Thus, a complete composition depth profile was obtained and is presented in Fig. $5 \mathrm{~b}$ for the $P_{0.5} d_{5}$ and $P_{2.0} d_{8}$ annealed samples. For the $P_{0.5} d_{5}$ annealed samples, one can detect a copper oxide phase for the first 1,000 s of etching time. After removing this $\mathrm{CuO} \mathrm{SL}$, for etching time higher than $1200 \mathrm{~s}$, one can detect copper, iron, and oxygen with the $\mathrm{CuFe}_{2} \mathrm{O}_{4}$ stoichiometry. Finally, for etching time higher than $5000 \mathrm{~s}$, silicon is detected after the complete removal of the films. The depth profile of the $P_{2.0} d_{8}$ annealed samples is identical to that of the $P_{0.5} d_{5}$ one except for the lower etching time for each layer as shown in Fig. 5b. The total etching time required to reveal silicon in the substrate is attributed to the total thicknesses of the films. The thickness of the surface and HLs can then be qualitatively deduced from the etching time. Irrespective of the deposition conditions, the XPS depth profiles of the annealed samples revealed a structure in two layers which is consistent with the FE-SEM images as schematically represented in Fig. 4a. The upper layer is composed of $\mathrm{CuO}$ while the HL corresponds to $\mathrm{CuFe}_{2} \mathrm{O}_{4}$. One can notice that the upper layer has different thicknesses depending on the deposition conditions and is in good agreement with the FE-SEM measurements.

The elemental compositions of thin films were also investigated by EPMA analysis. The software Stratagem $(\subset)$ 
Fig. 5 a XPS spectrum after removing the ten first nanometers of the polluted surface of the $P_{0.5} d_{5}$ sample annealed in air at $450{ }^{\circ} \mathrm{C}$ for $12 \mathrm{~h}$. Zoom of the Cu2p spectra is presented in insert. b XPS depth profiles of the annealed samples using ion beam.

Schematic representation of the heart and SLs noted HL and SL, respectively, and determined by XPS and SEM analyses are shown for comparison

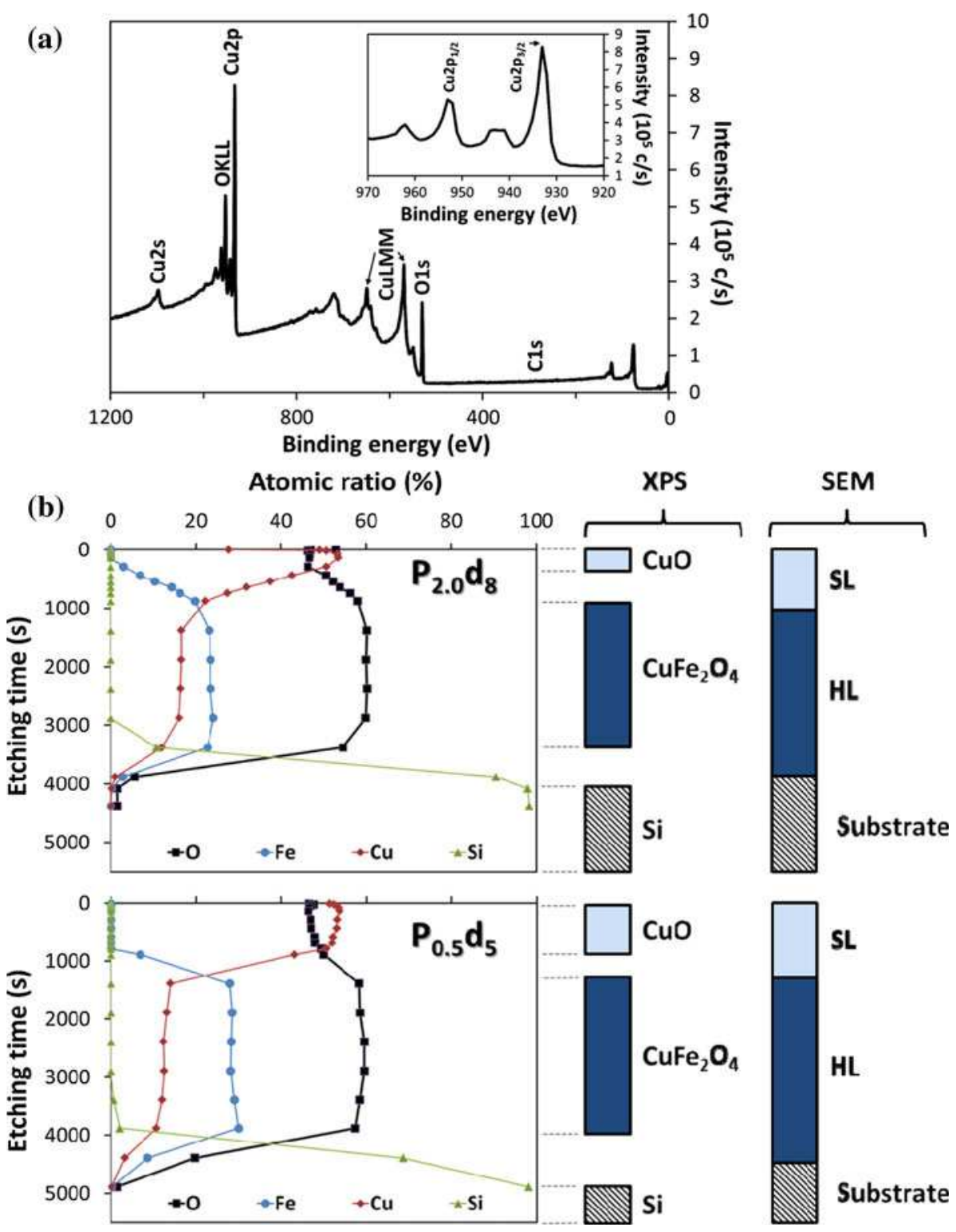

[29] allows us to simulate two layers with different compositions which are one over the other. In order to precisely quantify the HL composition, the upper layer was defined as the stoichiometric compound $\mathrm{CuO}$. The atomic percentages of the HL obtained in this condition are presented in Table 2. Cations to oxygen ratios are closed to 0.75 and is in agreement with the nominal composition of a spinel phase, which contains three cations for four oxygen atoms. After normalizing to three cations per formula units, the average composition is $\mathrm{Cu}_{0.9} \mathrm{Fe}_{2.1} \mathrm{O}_{4.0}$ which is in good agreement with $\mathrm{CuFe}_{2} \mathrm{O}_{4}$ determined by XPS measurements within the limits of the accuracy of each technique.

In the light of this original rearrangement into two stacked layers, the preferred detection of the tenorite phase over the cupro-spinel phase by GIXRD and Raman measurements (Figs. 1, 3) is explained. In both cases, the characteristic signal of the HL is partially hidden by the upper $\mathrm{CuO}$ layer. In order to improve the signal of the $\mathrm{CuFe}_{2} \mathrm{O}_{4} \mathrm{HL}, \mathrm{GXRD}$ analyses was done by varying grazing angles $\alpha$ from 0.25 to $3.5^{\circ}$. In this case, as $\alpha$ increases, i.e., as the incoming $\mathrm{X}$-rays penetrates more deeply in the film, intensity of $\mathrm{CuFe}_{2} \mathrm{O}_{4}$ (311) peak increases with a coupled decrease of the $\mathrm{CuO}$ (111) peak as shown in Fig. 6a. Single $\mathrm{CuFe}_{2} \mathrm{O}_{4}$ characteristic peak were also observed after the complete removal of the $\mathrm{CuO}$ SL by selective chemical etching in $\mathrm{NH}_{4} \mathrm{OH} 28 \%$ [30] for $48 \mathrm{~h}$ using conventional GIXRD (Fig. 6b) and Raman spectroscopy (Fig. 6c) experiment.

All these experiments showed two stacked layers arrangement for all the annealed samples. Systematically, the upper layer is made of $\mathrm{CuO}$ and the composition of the $\mathrm{HL}$ is very close to $\mathrm{CuFe}_{2} \mathrm{O}_{4}$. These observations are 
Table 2 Chemical analysis determined by EPMA and cation to oxygen ratio for the HL for the air-annealed samples fixed to $\mathrm{CuO}$

\begin{tabular}{lllll}
\hline Deposition conditions & $P_{0.5} d_{5}$ & $P_{0.5} d_{8}$ & $P_{2.0} d_{5}$ & $P_{2.0} d_{8}$ \\
$P \times d($ Pa.cm) & 2.5 & 4.0 & 10 & 16
\end{tabular}

HL (HL)

\begin{tabular}{lllll}
$\mathrm{Cu}\left(\%{ }^{\text {at }}\right)$ & $12.6(2)$ & $12.0(2)$ & $12.2(2)$ & $12.0(2)$ \\
$\mathrm{Fe}\left(\%{ }^{\text {at }}\right)$ & $30.5(2)$ & $30.0(2)$ & $30.0(2)$ & $31.1(2)$ \\
$\mathrm{O}\left(\%{ }^{\text {at }}\right)$ & $56.7(6)$ & $57.6(6)$ & $56.0(6)$ & $57.0(6)$ \\
Cations to oxygen ratio & $0.76(2)$ & $0.73(2)$ & $0.75(2)$ & $0.75(2)$ \\
Formulae & $\mathrm{Cu}_{0.9} \mathrm{Fe}_{2.1} \mathrm{O}_{3.9}$ & $\mathrm{Cu}_{0.9} \mathrm{Fe}_{2.1} \mathrm{O}_{4.1}$ & $\mathrm{Cu}_{0.9} \mathrm{Fe}_{2.1} \mathrm{O}_{4.0}$ & $\mathrm{Cu}_{0.8} \mathrm{Fe}_{2.2} \mathrm{O}_{4.0}$ \\
\hline
\end{tabular}

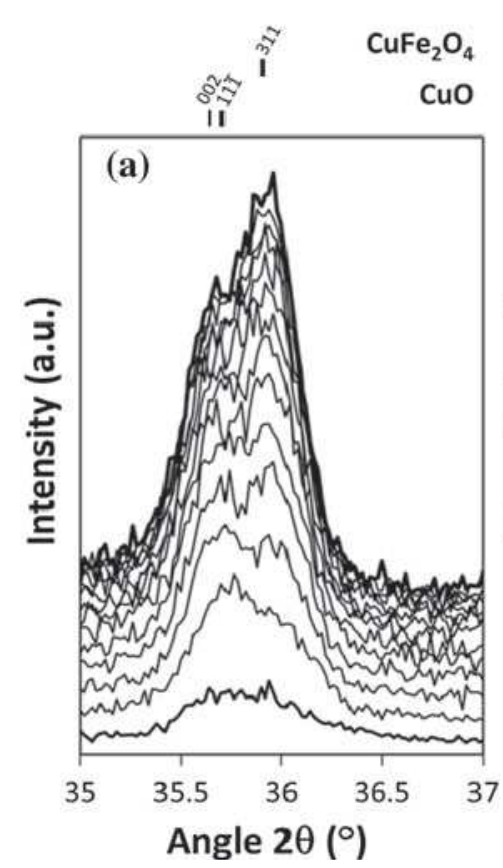

Fig. 6 a GXRD patterns with different grazing angles $\alpha$ ranging from 0.25 to $3.50^{\circ}$ of the $P_{0.5} d_{5}$ sample after air annealing, $\mathbf{b}$ XRD patterns of the $P_{0.5} d_{5}$ sample after air annealing and chemical attack by $\mathrm{NH}_{4} \mathrm{OH} 28 \%$ for $48 \mathrm{~h}$. Sample before the chemical attack is plotted

consistent with the formation of $1 \mathrm{~mol}$ of $\mathrm{CuO}$ for $1 \mathrm{~mol}$ of $\mathrm{CuFe}_{2} \mathrm{O}_{4}$, as predicted by Eq. 2. Moreover, the smaller thickness of the $\mathrm{CuO}$ SL compared to the $\mathrm{CuFe}_{2} \mathrm{O}_{4} \mathrm{HL}$ can be related to its significantly smaller molar volume (12.21 and $44.13 \mathrm{~cm}^{3} / \mathrm{mol}$ for $\mathrm{CuO}$ and $\mathrm{CuFe}_{2} \mathrm{O}_{4}$, respectively). However, despite their identical compositions, thicknesses of the surface and HLs are not equivalent for all the samples and seem to be dependent on the metallic copper concentration before the annealing treatment. The greater the metallic copper concentration is on the as-deposited sample, the thicker the SL becomes after annealing.

\section{Void fraction}

According to the previous work [13], composition of all the as-deposited samples is represented by the $A$ ratio of Eq. 1 . in dashed line for comparison. c Raman spectra of the same sample before (dashed line) and after (bold line) chemical attack by $\mathrm{NH}_{4} \mathrm{OH}$. Raman spectra of $\mathrm{CuO}$ and $\mathrm{CuFe}_{2} \mathrm{O}_{4}$ commercial powders are also plotted for comparison

The annealing treatment of the as-deposited samples is represented by the Eq. 2 and leads in any case to an equimolar distribution of cupro-spinel and tenorite phases. For one initial mole of $\mathrm{CuFeO}_{2}$ target material, by knowing the $A$ ratio (0.31, 0.22, 0.12, and 0.03 for the $P_{0.5} d_{5}, P_{0.5} d_{8}, P_{2.0} d_{5}$, and $P_{2.0} d_{8}$ samples, respectively) and the molar volume of each phase $\left(7.11,23.44,12.21,44.56\right.$, and $44.13 \mathrm{~cm}^{3} / \mathrm{mol}$ for $\mathrm{Cu}$, $\mathrm{Cu}_{2} \mathrm{O}, \mathrm{CuO}, \mathrm{Fe}_{3} \mathrm{O}_{4}$, and $\mathrm{CuFe}_{2} \mathrm{O}_{4}$, respectively), the theoretical molar volume of the as-deposited and annealed materials can be deduced. They are presented in Table 3. For each deposition condition, the oxidation process represented by Eq. 2 generates a volume expansion. The latter can be assimilated to an increase in the film thickness due to the twodimensional character of the material. As a result, the theoretical thicknesses of all the annealed films can be calculated. All results of these calculations are shown in Table 3 with the 
Table 3 Comparison between experimental and theoretical thicknesses of the annealed samples

${ }^{\text {a }}$ Determined from Eq. 1 and $A$ ratio, i.e.,

$V_{\mathrm{i}}=A V_{\mathrm{Cu}}+((1-A) / 2)$

$V_{\mathrm{Cu}_{2} \mathrm{O}}+((9-A) / 24) V_{\mathrm{Fe}_{3} \mathrm{O}_{4}}$

${ }^{\mathrm{b}}$ Determined from Eq. 2, i.e., $V_{\mathrm{f}}=1 / 2 V_{\mathrm{CuO}}+1 / 2 V_{\mathrm{CuFe}_{2} \mathrm{O}_{4}}$

${ }^{c}$ Determined from FE-SEM measurements (see Fig. 4)

Table 4 Surface and HLs analysis and void fraction determination
${ }^{a}$ Determined from SEM
measurements (see Fig. 4)

\begin{tabular}{lllll}
\hline Deposition conditions & $P_{0.5} d_{5}$ & $P_{0.5} d_{8}$ & $P_{2.0} d_{5}$ & $P_{2.0} d_{8}$ \\
$P \times d($ Pa.cm) & 2.5 & 4.0 & 10 & 16 \\
As-deposited films & & & & \\
$\quad$ Copper content A (mol) & $0.31(3)$ & $0.22(3)$ & $0.12(3)$ & $0.03(3)$ \\
$\quad$ Molar volume $V_{\mathrm{i}}\left(\mathrm{cm}^{3} / \mathrm{mol}\right)^{\mathrm{a}}$ & $26.3(2)$ & $26.8(2)$ & $27.5(2)$ & $28.1(2)$ \\
$\quad$ Thickness $t_{\mathrm{i}}(\mathrm{nm})$ & 300 & 300 & 300 & 300 \\
Air-annealed films & & & & \\
$\quad$ Molar volume $V_{\mathrm{f}}\left(\mathrm{cm}^{3} / \mathrm{mol}\right)^{\mathrm{b}}$ & 28.17 & 28.17 & 28.17 & 28.17 \\
$\quad$ Volume expansion $\Delta V=\left(V_{\mathrm{f}}-V_{\mathrm{i}}\right) / V_{\mathrm{i}}(\%)$ & $7.2(8)$ & $4.9(8)$ & $2.4(7)$ & $0.3(7)$ \\
$\quad$ Calculated thickness $t_{\mathrm{f}}^{\text {calc. }}=t_{\mathrm{i}}(1+\Delta V)(\mathrm{nm})$ & $322(2)$ & $315(2)$ & $307(2)$ & $301(2)$ \\
$\quad$ Measured thickness $t_{\mathrm{f}}^{\text {meas. }}(\mathrm{nm})^{\mathrm{c}}$ & $390(5)$ & $345(5)$ & $350(5)$ & $310(5)$ \\
$\quad$ Void fraction $\varnothing=1-t_{\mathrm{f}}^{\text {calc. }} / t_{\mathrm{f}}^{\text {meas. }}(\%)$ & $17(3)$ & $9(3)$ & $12(3)$ & $3(3)$ \\
\hline
\end{tabular}

\begin{tabular}{|c|c|c|c|c|}
\hline Deposition conditions & $P_{0.5} d_{5}$ & $P_{0.5} d_{8}$ & $P_{2.0} d_{5}$ & $P_{2.0} d_{8}$ \\
\hline$P \times d(\mathrm{~Pa} . \mathrm{cm})$ & 2.5 & 4.0 & 10 & 16 \\
\hline \multicolumn{5}{|l|}{$\mathrm{CuO} \mathrm{SL}(\mathrm{SL})$} \\
\hline Calculated thickness $t_{\mathrm{SL}}^{\text {calc. }}=22 \% t_{\mathrm{f}}^{\text {calc. }}(\mathrm{nm})$ & $70.8(4)$ & $69.3(4)$ & $67.5(4)$ & $66.2(4)$ \\
\hline Measured thickness $t_{\mathrm{SL}}^{\text {meas. }}(\mathrm{nm})^{\mathrm{a}}$ & $120(5)$ & $100(5)$ & $80(5)$ & $60(5)$ \\
\hline Void fraction $\varnothing_{\mathrm{SL}}=1-t_{\mathrm{SL}}^{\text {calc. }} / t_{\mathrm{SL}}^{\text {meas. }}(\%)$ & $41(3)$ & $31(3)$ & $15(4)$ & $\mathrm{n} / \mathrm{a}$ \\
\hline \multicolumn{5}{|l|}{$\mathrm{CuFe}_{2} \mathrm{O}_{4} \mathrm{HL}(\mathrm{HL})$} \\
\hline Calculated thickness $t_{\mathrm{HL}}^{\text {calc. }}=78 \% t_{\mathrm{f}}^{\text {calc. }}(\mathrm{nm})$ & $251(2)$ & $246(2)$ & $239(2)$ & $235(2)$ \\
\hline Measured thickness $t_{\mathrm{HL}}^{\text {meas. }}(\mathrm{nm})^{\mathrm{a}}$ & $270(5)$ & $245(5)$ & $270(5)$ & $245(5)$ \\
\hline Void fraction $\varnothing_{\mathrm{HL}}=1-t_{\mathrm{HL}}^{\text {calc. }} / t_{\mathrm{HL}}^{\text {meas. }}(\%)$ & $7(1)$ & $0(1)$ & $11(1)$ & $4(1)$ \\
\hline
\end{tabular}

measured thicknesses determined by FE-SEM cross-sectional micrographs for comparison.

For all the samples, the measured thicknesses are always greater than the calculated ones. This difference is due to the porosity, which is not taken into account in the theoretical molar volume calculation. The complex oxidation phenomena are responsible for the porosity. Especially, the oxidation of metallic copper particles leads to the copper migration at the surface [31], leading to voids inside the initial cermet material as previously shown for $\mathrm{Cu}-\mathrm{Ni}$ cermets [32]. The void fraction $\varnothing$ is estimated for all the samples from the difference between the measured and calculated thicknesses $\left(\varnothing=\frac{1-t_{\mathrm{f}}^{\text {calc. }}}{t_{\mathrm{f}}^{\text {meas. }}}\right)$. The calculated void fractions are detailed and reported in Table 3. One can note that the maximum void fraction is obtained for the $P_{0.5} d_{5}$ sample and is $17.4 \%$. The lowest value is for $P_{2.0} d_{8}$ sample with a porosity value $2.9 \%$.

By applying the same calculation for the total thickness of the films and for each layer, it is possible to estimate the distribution of the void fraction of the heart and SLs. In this case, the calculated thickness of each layer estimated from the total theoretical thickness distribution is proportional to the molar volume of the $\mathrm{CuO}$ and $\mathrm{CuFe}_{2} \mathrm{O}_{4}$, i.e., at 22 and $78 \%$, respectively. The measured thicknesses were determined from FE-SEM measurements also. All of these calculations are reported in Table 4. One can note from these results that the void fraction is relatively low in the HL for all the samples. In the SL, the void fraction is more important and increases for the films deposited at low $P \times d$ product, i.e., for films which have the highest metallic copper content in the as-deposited forms. A linear dependence between the porosity in the SL and the metallic copper content in the as-deposited sample can be deduced as shown in the Fig. 7. This indicates that copper oxidation process has a key role in the creation of the stacking layers: the $\mathrm{CuO}$ porous SLs is mainly due to the metallic copper oxidation coupled with a migration at the surface, while the $\mathrm{CuFe}_{2} \mathrm{O}_{4} \mathrm{HL}$ results from the reaction between copper oxides and mixed valence defect ferrite.

This specific arrangement in heart and SLs with a majority of the void fraction distributed in the SL and at the interface of the heart and SLs was observed in TEM crosssectional view (Fig. 8).

\section{Gas sensing properties}

For thin film semiconductor metal oxide based gas sensors, the porosity of the sensing layer is an important parameter [33-36]. Gas diffusion through the porosity can cause 


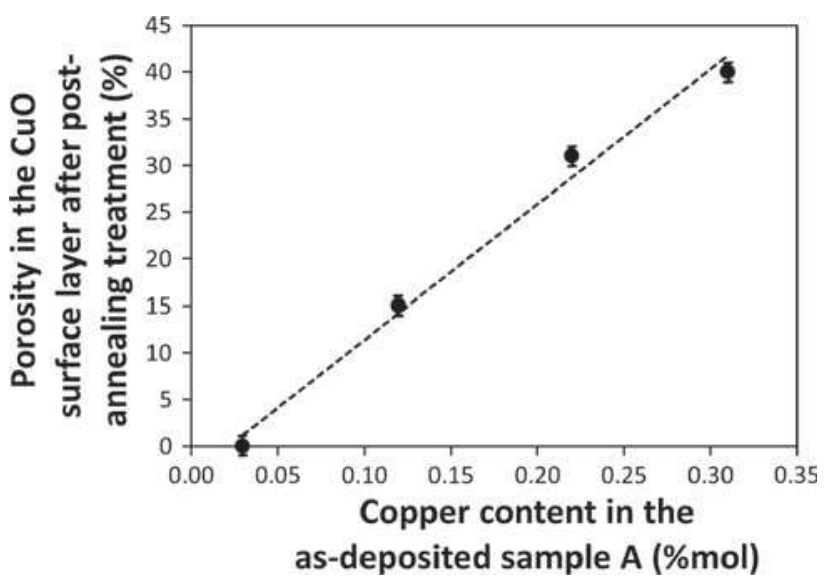

Fig. 7 Plot of the porosity in the $\mathrm{CuO}$ SL of the samples annealed $12 \mathrm{~h}$ at $450{ }^{\circ} \mathrm{C}$ under air versus the copper content in the as-deposited samples. Dashed line is only a guideline for the eyes

changes in electrical properties of film, making the gas detection easier. Moreover, the co-existence of $\mathrm{n}$ - and p-type semi-conducting phases can enhance sensitivity and selectivity to reducing or oxidizing gas species.

Films having this interesting microstructure have significant interest for technological applications and were tested for their ability to detect $\mathrm{CO}_{2}$ gas. In order to evaluate the $\mathrm{CO}_{2}$ sensing properties, all the measurements were carried out at constant temperature with alternative introduction of air and a mixture of air added to 5,000 ppm of $\mathrm{CO}_{2}$. The highly porous $P_{0.5} d_{5}$ film and the quite dense sample $P_{2.0} d_{8}$ were both tested under controlled atmosphere. Normalized resistance as a function of time under alternative introduction of air and $\mathrm{CO}_{2}$ was plotted for the $P_{0.5} d_{5}$ sample and is shown in the Fig. 9.

When $\mathrm{CO}_{2}$ gas is introduced in the testing chamber, the electrical resistance of the whole film decreases, irrespective of the deposition conditions. Due to the oxidizing character of $\mathrm{CO}_{2}$, the decrease in electrical resistance could be related to a p-type semiconducting property of the layer interacting with the gas. This could indicate a preferential interaction of $\mathrm{CO}_{2}$ with $\mathrm{CuO}$ upper layer, which displays such semiconducting properties, contrary to $\mathrm{CuFe}_{2} \mathrm{O}_{4}$, which is clearly a n-type semiconductor above $177^{\circ} \mathrm{C}$ [37]. The preferential interaction with $\mathrm{CuO}$ is not surprising because this layer is located at the top of the two-phased material studied. However, this original rearrangement into two layers offers the possibility to detect $\mathrm{CO}_{2}$, whereas the two elements which are separated are not sensitive to this gas. This confirms the advantage of working with a mixture of p- and n-type semiconductors.

Moreover, this layer is more active when its porosity increases, as demonstrated by the highest sensitivity of the $P_{0.5} d_{5}$, which displays the highest porosity among the samples studied. The response of the $P_{0.5} d_{5}$ sample is around $40 \%$ against $30 \%$ for the $P_{2.0} d_{8}$ (Table 5). Moreover, the presence of porosity in the $P_{0.5} d_{5}$ sample leads to reduced response and recovery time to half of that of $P_{2.0} d_{8}$ sample $\left(t_{90} \%=55 \mathrm{~min}\right.$ and $\operatorname{tr}_{90} \%=8 \mathrm{~min}$ for $P_{0.5} d_{5} ; t_{90 \%}=100 \mathrm{~min}$ and $\operatorname{tr}_{90 \%}=20 \mathrm{~min}$ for $P_{2.0} d_{8}$ ).

Preliminary tests were already reported for this system [11] but further investigations such as testing the effect of the selectivity and atmospheric humidity are required to optimize sensing parameters.

\section{Summary and conclusion}

GIXRD, TXRD, and Raman spectroscopy analyses showed that the annealing in air of $\mathrm{Cu} /\left(\mathrm{Cu}_{2} \mathrm{O}, \mathrm{Cu}_{x} \mathrm{Fe}_{3-x} \mathrm{O}_{4}\right)$ nanocomposites with various metallic copper content led to $\mathrm{CuO} / \mathrm{CuFe}_{2} \mathrm{O}_{4}$ thin films. A self-organization into two stacked layers was systematically observed by FE-SEM experiments in all the samples. EPMA and XPS studies revealed that the SL was made of $\mathrm{CuO}$ while the $\mathrm{HL}$ was composed of $\mathrm{CuFe}_{2} \mathrm{O}_{4}$. This specific structure was explained by the metallic copper diffusion during the oxidation process of the as-deposited samples. The presence of porosity, in particular in the upper layer, was evident by
Fig. 8 TEM cross-sectional view of the $P_{0.5} d_{5}$ sample after annealing at $450{ }^{\circ} \mathrm{C}$ for $12 \mathrm{~h}$
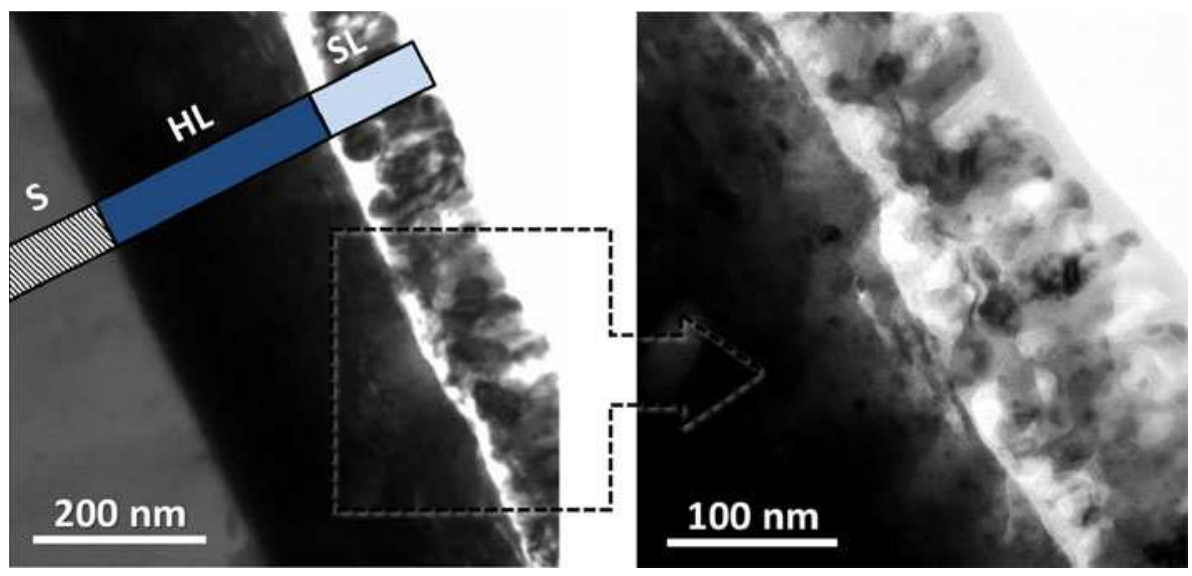


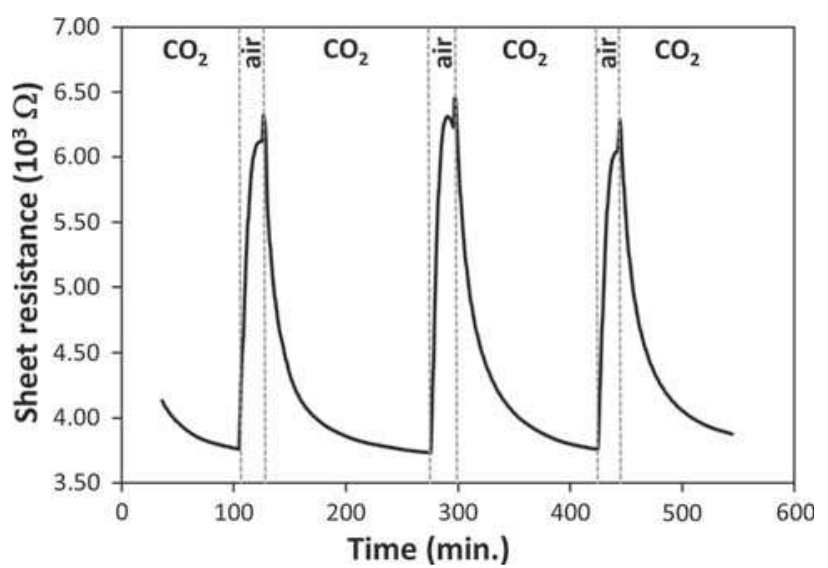

Fig. 9 Evolution of the electrical resistance of $\mathrm{CuO}-\mathrm{CuFe}_{2} \mathrm{O}_{4}$ deposited at $P_{0.5} d_{5}$ versus time and atmosphere air/ $/ \mathrm{CO}_{2}$ $\left(\left[\mathrm{CO}_{2}\right]=5,000 \mathrm{ppm}\right)$ at $250{ }^{\circ} \mathrm{C}$

Table 5 Comparison of response (absolute value), response time $t_{90} \%$, and recovery time $\operatorname{tr}_{90} \%$ of dense and porous samples under $5,000 \mathrm{ppm} \mathrm{CO}_{2}$

\begin{tabular}{lcr}
\hline Deposition conditions & $P_{0.5} d_{5}$ & $P_{2} d_{8}$ \\
Sensing characteristics & & \\
ISI (\%) & 40 & 32 \\
$t_{90 \%}(\mathrm{~min})$ & 55 & 100 \\
$\operatorname{tr}_{90 \%}(\mathrm{~min})$ & 8 & 20 \\
\hline
\end{tabular}

TEM and evaluated by comparing experimental and theoretical thicknesses. Indeed, we determined a clear correlation between porosity obtained in the $\mathrm{CuO} \mathrm{SL}$ after air annealing and metallic copper content initially present in the as-deposited samples. Void fraction ranging from 0 to $41 \%$ can then be obtained by controlling the as-deposited elaboration step described in the part I of this paper. The highest porosities were observed for films deposited with low argon pressure and low target-to-substrate distance $\left(P_{0.5} d_{5}\right)$. Due to their specific self-organization into p- and n-type layers along with their high porosity, such films exhibited high sensitivity to $\mathrm{CO}_{2}$. Sensing characteristics of our self-organized bilayer could be favorably used to make $\mathrm{CO}_{2}$ sensors based on semiconductor sensitive layer.

\section{References}

1. Fernandez-Garcia M, Martınez-Arias A, Hanson JC, Rodriguez JA (2004) Chem Rev 104:4063

2. Wei S, Wang Q, Zhu J, Sun L, Lin H, Guo Z (2011) Nanoscale 3:4474
3. Sanchez C, Rozes L, Ribot F, Laberty-Robert C, Grosso D, Sassoye C, Boissiere C, Nicole L (2010) C R Chimie 13:3

4. Simon Q, Barreca D, Gasparotto A, Maccato C, Montini T, Gombac V, Fornasiero P, Lebedev OI, Turner S, Van Tendeloo G (2012) J Mater Chem 22:11739

5. Ishihara T, Kometani K, Hasida M, Takita Y (1991) J Electrochem Soc 138:173

6. Barreca D, Comini E, Gasparotto E, Maccato C, Sadad C, Sberveglieri G, Tondello E (2009) Sens Actuators B 141:270

7. Kim YS, Hwang IS, Kim SJ, Lee CY, Lee JH (2008) Sens Actuators B 135:298

8. Ishihara T, Kometani K, Nishi Y, Takita Y (1995) Sens Actuator B 28:49

9. Haeusler A, Meyer JU (1996) Sens Actuators B 34:388

10. Xu JC, Hunter GW, Lukco D, Liu CC, Ward BJ (2009) IEEE Sens J 9:235

11. Chapelle A, Oudrhiri-Hassani F, Presmanes L, Barnabé A, Tailhades P (2010) Appl Surf Sci 256:4715

12. Ishihara T, Higuchi M, Takagi T, Ito M, Nishiguchia M, Takita $Y$ (1998) J Mater Chem 8:2037

13. Barnabé A, Chapelle A, Presmanes L, Tailhades P (2012) J Mater Sci. doi:10.1007/s10853-012-7123-6

14. Liao B, Wei Q, Wang K, Liu Y (2001) Sens Actuators B 80:208

15. O'Reilly M, Jiang X, Beechinor JT, Lynch S, Ni Dheasuna C, Patterson JC, Crean GM (1995) Appl Surf Sci 91:152

16. Yakubi A, Tanaka S (2011) Mater Res Bull 46:2323

17. Mugnier E, Barnabé A, Presmanes L, Tailhades P (2008) Thin Solid Films 516:1453

18. Prisedsky VV, Vinogradov VM (2004) J Solid State Chem $177: 4258$

19. Egger K, Feitknecht W (1962) Helv Chim Acta 65:2043

20. Tailhades P, Gillot B, Rousset A (1997) J Phys IV 7:249

21. Khvan AV, Fabrichnaya OB, Savinykh G, Adam R, Seifert HJ (2011) J Phase Equilib Diff 32:498

22. Kenfack F, Langbein H (2004) Cryst Res Technol 39:1070

23. O'Keeffe M, Stone FS (1962) Roy Soc Lond 267:501

24. Li J, Mayer JW (1991) J Appl Phys 70:2820

25. Gong YS, Lee C, Yang CK (1995) J Appl Phys 77:5422

26. Wallbank B, Main IG, Johnson CE (1974) J Electron Spectrosc 5:259

27. Kim KS (1974) J Electron Spectrosc 3:217

28. Watts JF, Wolstenholme J (2003) An introduction to surface analysis by XPS and AES, Chapt 3.2.5. Wiley, London

29. Pouchou JL, Pichoir F (1991) STRATAgem thin film analysis software and thickness determination. http://www.samx.com/micro analysis/products/stratagem_us.html

30. Benko F, Koffyberg F (1987) J Phys Chem Solids 48:431

31. Mugnier E, Pasquet I, Barnabé A, Presmanes L, Bonningue C, Tailhades P (2005) Thin Solid Films 493:49

32. Rioult F, Pijolat M, Valdivieso F, Prin-Lamaze MA (2006) J Am Ceram Soc 89:996

33. Sakai G, Matsunaga N, Shimanoe K, Yamazoe N (2001) Sens Actuators B 80:125

34. Baik NS, Sakai G, Shimanoe K, Miura N, Yamazoe N (2000) Sens Actuators B 65:97

35. Shimizu Y, Maekawa T, Nakamura Y, Egashira M (1998) Sens Actuators B 46:163

36. Seo MH, Yuasa M, Kida T, Huh JS, Shimanoe K, Yamazoe N (2009) Sens Actuators B 137:513

37. Mahajan RP, Patankar KK, Kothale MB, Patil SA (2000) Bull Mater Sci 23:273 